\title{
Henryana magnifica Yoshimoto (Hymenoptera: Eulophidae) in Brazil: New Records for the Amazon Rainforest and Brazilian Dry Forest
}

\author{
Daniell Rodrigo Rodrigues Fernandes ${ }^{1} \bowtie$, Karine Schoeninger², \\ Rogéria Inês Rosa Lara ${ }^{2}$ \& Nelson Wanderley Perioto
}

1. Instituto Nacional de Pesquisas da Amazônia, e-mail: daniellrodrigo@hotmail.com (Autor para correspondência ${ }^{\bowtie}$ ), karine.schoeninger@gmail.com. 2. APTA - Agência Paulista de Tecnologia dos Agronegócios, e-mail: rirlara@yahoo.com.br, nperioto2@gmail.com.

\section{EntomoBrasilis 7 (3): 241-243 (2014)}

Abstract. Henryana magnifica Yoshimoto (Hymenoptera: Eulophidae) is reported for the first time in an Amazon rainforest area of Amazonas State and in a Brazilian Dry Forest area of Rio Grande do Norte State, Brazil.

Keywords: Amazon; Caatinga; Chalcidoidea; Tetrastichinae.

\section{Henryana magnifica Yoshimoto (Hymenoptera: Eulophidae) no Brasil: Novos registros para a Floresta Amazônica e Caatinga}

Resumo. Henryana magnifica Yoshimoto (Hymenoptera: Eulophidae) é relatada pela primeira vez em uma área de Floresta Amazônica do Estado do Amazonas e em uma área de Caatinga no Rio Grande do Norte, Brasil.

Palavras-Chave: Amazônia; Caatinga; Chalcidoidea; Tetrastichinae.

$\int \frac{\square}{\square}$ Cenryana magnifica Yoshimoto

(Hymenoptera: Eulophidae) is a peculiar Tetrastichinae species found species based on specimens collected by Fritz Plaumann in Nova Teutonia, Santa Catarina, Brazil. Subsequently LASALle (1994) listed the North American records for the states of Florida, Georgia, Missouri and Virginia (USA).

In the state of Rio Grande do Norte, only four species of Chalcidoidea have been reported:Dilocanthaflavicornis (Walker) (Eucharitidae), Tetrastichus giffardianus Silvestri (Eulophidae), Heimbra bicolor Subba Rao and Symbra potiguara Perioto \& Fernandes (Eurytomidae) (Heraty 1998; Costa et al. 2005; Fernandes et al. 2012). Rio Grande do Norte has nearly $95 \%$ of its area covered with Brazilian Dry Forest (Caatinga biome) and little is known about the entomofauna associated with that type of vegetation.

In contrast, in the state of Amazonas, 124 Chalcidoidea species have been reported (NOYES 2014). However, only six are Eulophidae: Alveoplectrus corumbae (Ashmead), Apleurotropis strix Hansson, Emersonella niveipes Girault; Galeopsomyia macaxeira Perioto, Costa \& Lara; Horismenus liturgusae Hansson \& Schoeninger and Omphale insetosa Hansson (CARROLL 1978; De Santis 1980; Hansson 2004, 2010; РеRioto et al. 2011; HANSson et al. 2014). Amazonas is totally covered by Amazon forest and little is known about the Eulophidae fauna associated with that rainforest.

The current study reports, for the first time, the occurrence of $H$. magnifica in an Amazon rainforest of Amazonas State and in a Brazilian Dry Forest of Rio Grande do Norte State.

The specimens studied were collected with a Malaise trap in a Brazilian Dry Forest site (6 $6^{\circ} 6^{\prime} 18^{\prime \prime} \mathrm{S} / 37^{\circ} 37^{\prime} 41^{\prime \prime} \mathrm{W}$ ) (Figure 1) and in an Amazon rainforest site $\left(2^{\circ} 53^{\prime} 42.18^{\prime \prime S} / 59^{\circ} 59^{\prime} 10.58^{\prime \prime} \mathrm{W}\right)$
(Figure 2), situated at Patu, Rio Grande do Norte, Brazil and at Manaus, Amazonas, Brazil, respectively (Figure 3).

Observations were carried out using a Leica MZ 9.5 stereomicroscope under a fluorescent light source. Color images were obtained using a Leica DFC295 digital camera attached to a Leica M205C APO stereomicroscope, illuminated by a highly diffuse illumination dome Leica LED5000 HDI. The serial images from different layers were combined using the Helicon Focus software (version 5.2). The figure was prepared using Adobe Photoshop v.13.

The material is deposited at the entomological collection of APTA Ribeirão Preto (LRRP), Ribeirão Preto, São Paulo, Brazil (N.W. Perioto, curator) and Coleção de Invertebrados of Instituto Nacional de Pesquisas da Amazônia (INPA), Manaus, Amazonas, Brazil (M.L. Oliveira, curator). Henryana magnifica (Figure 4) was identified using the original description (Yоsнгмото 1983).

A female specimen was collected in Rio Grande do Norte, Patu, Sítio Miranda in September of 2008, recorded by: D.R.R. Fernandes; institution Code: LRRP. The other specimen, a male, was collected in Amazonas, Manaus (Embrapa Amazônia Ocidental) in 05.I.2013, recorded by: K. Schoeninger; institution Code: INPA.

This species was previously reported in Brazil from Nova Teutônia, Santa Catarina, probably in a Brazilian Atlantic Forest. This report expands the limit range to the Amazon rainforest and the Brazilian Dry Forest. It is worth emphasizing that one of the sampled areas (Manaus) was near the guarana crop Paullinia cupana var. sorbilis (Mart.) Ducke (Figure 4). 


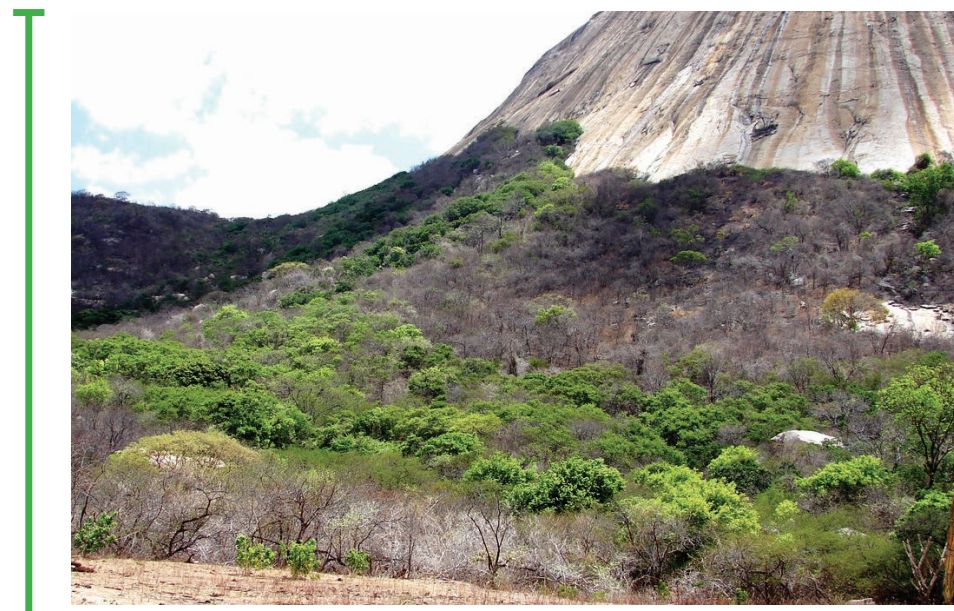

Figure 1. Area of Brazilian dry forest (Caatinga) at Patu, Rio Grande do Norte, Brazil.

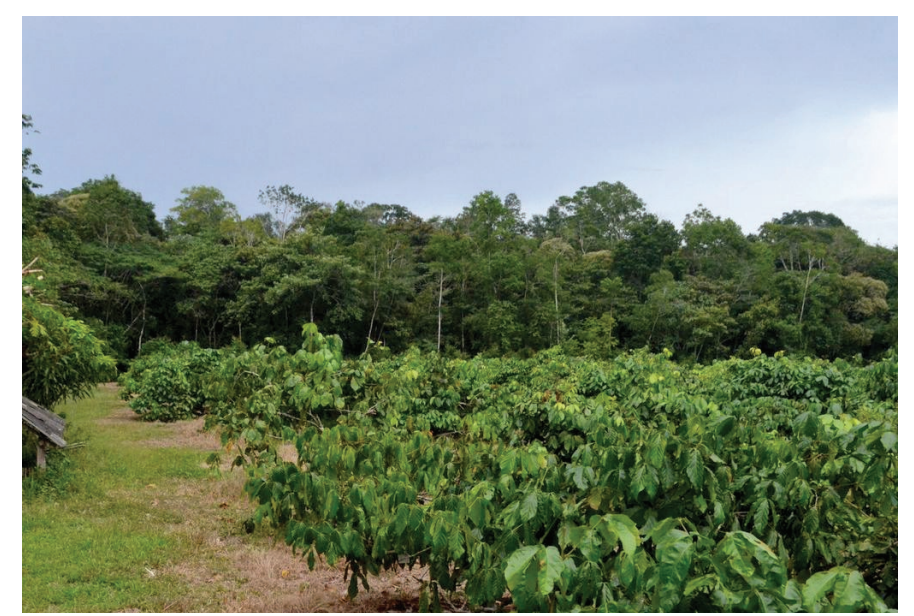

Figure 2. Area of Amazon rainforest (back) and Paullinia cupana var. sorbilis (Mart.) Ducke (Sapindaceae) (front) at Manaus, Amazonas, Brazil.

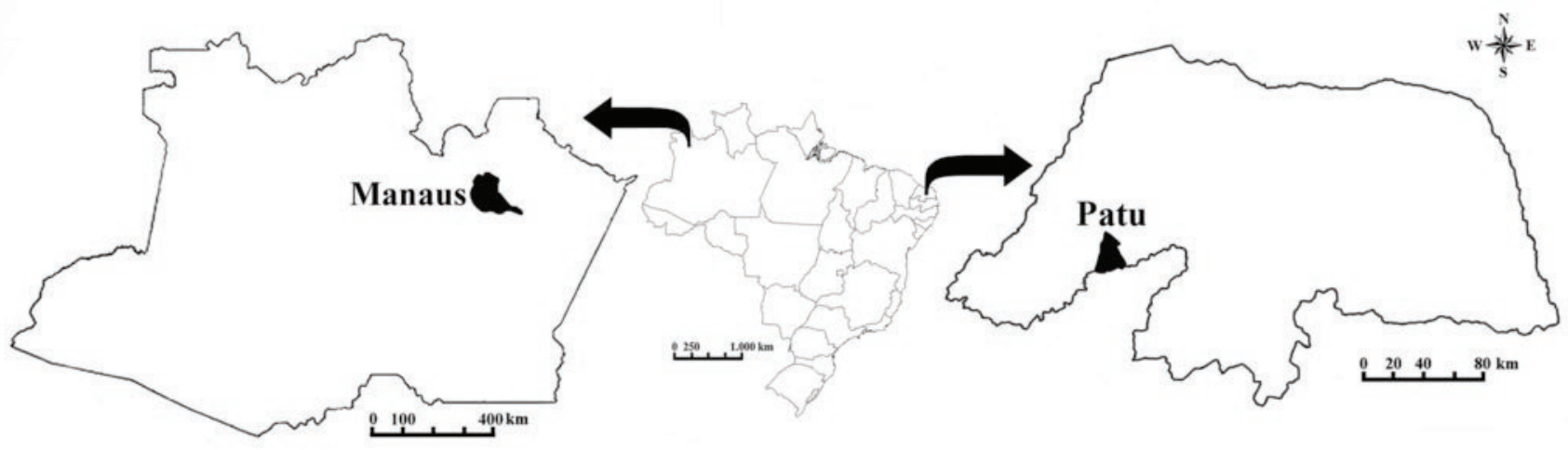

Figure 3. Collection sites, Manaus, Amazonas and Patu, Rio Grande do Norte, Brazil.

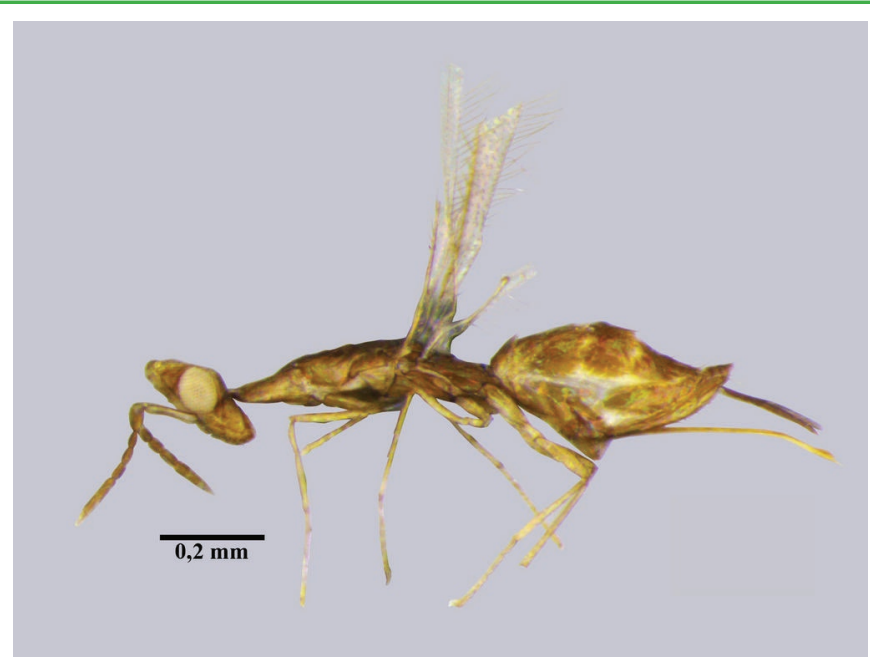

Figure 4. Henryana magnifica Yoshimoto, (female).

\section{ACKNOWLEDGEMENTS}

To CAPES for the postdoctoral fellowship granted to the first author (PNPD/CAPES), to Instituto Nacional de Ciência e Tecnologia dos Hymenoptera Parasitoides da Região Sudeste Brasileira (HYMPAR/Sudeste - CNPq/FAPESP/CAPES), for the financial support, and to Dr. Elton Lucio Araujo, Universidade Federal Rural do Semi-Árido, for logistical support.

\section{REFERENCES}

Carroll, C.R., 1978. Beetles, parasitoids and tropical morning glories: a study in host discrimination. Ecological Entomology, 3: $79-85$.

Costa, V.A., E.L. Araujo, J.A. Guimarães, A.S. Nascimento \& J.
LaSalle, 2005. Redescoberta de Tetrastichus giffardianus (Hymenoptera: Eulophidae) após 6o anos da sua introdução no Brasil. Arquivos do Instituto Biológico, 72: 539-541.

De Santis, L., 1980. Catalogo de los himenopteros brasileños de la serie Parasitica incluyendo Bethyloidea. Editora da Universidade Federal do Paraná, Curitiba, 395p.

Fernandes, D.R.R., R.I.R. Lara \& N.W. Perioto, 2012. A new species of Symbra (Hymenoptera, Eurytomidae, Heimbrinae) from dry forest in Brazil and new occurrence records for other Heimbrinae. Revista Brasileira de Entomologia, 56: 415-418. Hansson, C., 2004. Eulophidae of Costa Rica. Memoirs of the American Entomological Institute, 75: 1-537.

Hansson, C., 2010. Apleurotropis Girault (Hymenoptera: Eulophidae) new to tropical America, including six new species and biological records. Zootaxa, 2563: 35-52. 
Hansson, C., D.G. Pádua, K. Schoeninger, A.A. Agudelo \& M.L. Oliveira, 2014. A new species of Horismenus Walker (Hymenoptera, Eulophidae) from ootheca of Liturgusa Saussure (Mantodea, Liturgisidae) from Central Amazonas, Brazil. Journal of Hymenoptera Research, 37: 53-60.

Heraty, J.M., 1998. The genus Dilocantha (Hymenoptera: Eucharitidae). Proceedings of the Entomological Society of Washington, 100: 72-87.

LaSalle, J., 1994. North American genera of Tetrastichinae (Hymenoptera: Eulophidae). Journal of Natural History, 28: 109-236.

Noyes, J.S., 2014. Universal Chalcidoidea Database. Available in: <http://www.nhm.ac.uk/chalcidoids $>$. [Accessed: 09.25.2014].
Perioto, N.W., V.A. Costa \& R.I.R. Lara, 2011. Two new species of Galeopsomyia (Hymenoptera, Eulophidae) from Brazil: a correction of published mistakes. Revista de Agricultura, 86: 162-169.

Yoshimoto, C.M., 1983. A new genus of Tetrastichinae from the New World (Hymenoptera: Chalcidoidea: Eulophidae). Contributions of the American Entomological Institute, 20: 90-93.

\section{Received in: 06/04/2014}

Accepted in: 10/01/2014

\section{Suggested citation:}

Fernandes, D.R.R., K. Schoeninger, R.I.R. Lara \& N.W. Perioto, 2014. Henryana magnifica Yoshimoto (Hymenoptera: Eulophidae) in Brazil: New Records for the Amazon Rainforest and Brazilian Dry Forest. EntomoBrasilis, 7 (3): 241-243.

Available in: doi:10.12741/ebrasilis.v7i3.446
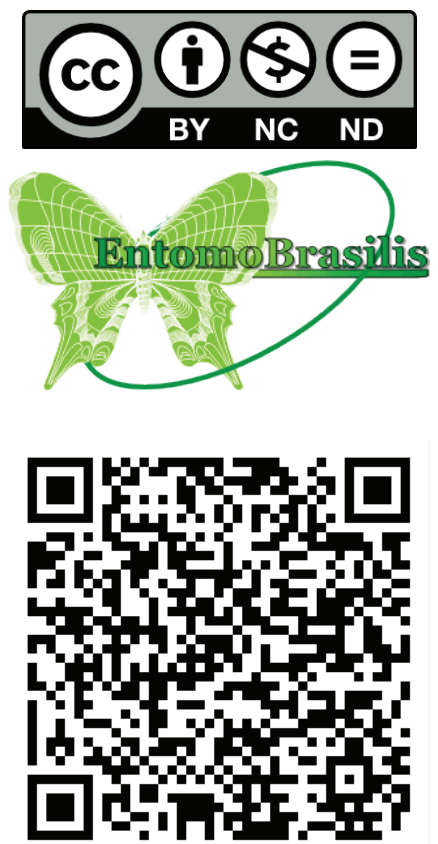